\title{
Haiti modsætter sig forandring
}

Jonathan Power

\section{International nødhjælp vil sikkert få Haiti på benene igen, men dagligliv og politik vil ikke ændres}

Graham Greenes store roman The Comedians, der foregår i Papa Docs diktatur i Haiti, giver næring til det fromme håb, at forfattere ikke er så magtesløse, som de som regel føler sig, og at en pen ligesom kugler kan koste blod. Hvordan kan man ellers forklare, at denne halvdel af en ret lille caribisk $\varnothing$ kan tiltrække sig mere presse, end den fortjener?

Det er delvis Graham Greenes fortjeneste. Han var - som jeg - draget til øen på grund af dens idiosynkratiske, men rige kultur og ikke mindst dens flammende vekslen mellem mørke og lys, som gennemtrænger det politiske liv.

Mens Greene fanger gangsteren Tonton Macoutes' grimhed og horror (paramilitær styrke under Papa Doc og siden sønnen Baby Doc. Red.), tegner han også et udførligt portræt af den civiliserede og omsorgsfulde Dr. Magiot (oprørsleder i The Comedians, filmatiseret i 1967.
Red.). Omverdenens fascination af mørkets kræfter var i de fleste europæiske og asiatiske kulturer repræsenteret af mænd med hvid hud, så det første billede huskes mere end det andet.

Det er også delvist fordi, Haiti ligger i Centralamerika, altså i USA's baghave. Og når politik i dette forarmede 'wrinkled wasteland' går galt, vil indbyggerne måske gå i bådene eller på planker og søge til Florida.

\section{Haiti vakler videre}

Haiti vil trods ødelæggende jordskælv, kup, opstande, mord og tyranners hærgen sikkert fortsætte sin vaklende kurs. International nødhjælp vil sikkert få det på benene igen, men dagligliv og politik vil ikke ændres. Der vil være den samme hvirvelvind af aktiviteter på fortovene - handlende og smede - en kakafoni af støj med modstridende 
lugte af afbrændt kul og stinkende åbne kloakker.

Kvinder med afrikansk sving i hofterne vil gå på gaderne med store baljer, fyldt med smuglergods, på hovederne. Skrivere vil sidde og vente på analfabetiske kunder i træernes skygge med deres gamle smældende skrivemaskiner foran sig. Børn vil strømme ud af skolegårdene i deres franske matrostøj og drage op til de riges huse i de kølige højder omkring byen.

Biler og hjemmelavede busser, proppet med passagerer og malet som fantasifuldt indpakningspapir, hver med sin besked 'Dieu est Bon' og 'L Armee Celeste', vil kapre kunder.

\section{Præsten Aristide}

Men udvikling til bedre levestandard vil det ikke blive til, for Haiti modsætter sig forandring. Haiti forbliver det fattigste land i den vestlige hemisfære. Dets skove er fældet, dets vandforsyninger stadig lavere.

Efter de 14 år med François Duvalier (Papa Doc) og så 15 år med hans søn, Jean-Claude (Baby Doc), kom og gik ledere med forbløffende hast, indtil der kom en sjælden valgsejr i et sjældent valg for 'den hulkindede, stirrende og svulstige' tidligere revolutionære præst, Jean-Bertrand Aristide.

Siden da er politik i Haiti begyndt at stabiliseres og blive noget mere demokratisk, selvom oprør fra tid til anden fortsætter med at forhindre reelle fremskridt. Politikerne synes stadig ude af stand til at levere varen. Aristide var som præst ved at ofre sit liv adskillige gange som ikkevoldelig kriger imod undertrykkelse og lovede meget, da han vandt præsidentposten med overraskende stor opbakning fra fattige og nedtrampede. Tragisk for Haiti smuldrede magten også i hans som i forgængernes hænder.

Han opnåede ikke meget, og i et desperat forsøg på at fastholde politisk magt greb han også til bander af bevæbnede slyngler og var parat til at tilsvine sig i korruption og rævestreger ved valg.

\section{Amerikansk indgriben}

USA har grebet ind to gange. Første gang i 1915 og anden gang i 1994. Omstændighederne - og resultatet lignede i forbavsende grad hinanden. I 1915 havde der været konstante oprør og seks præsidenter de foregående fire år. Periodens sidste præsident blev fanget af gadebander, hakket i stykket og hans legemsdele spredt rundt i byen.

Historien om amerikansk besættelse var så sandelig blandet. Den fremprovokerede modstand ved at genindføre det franske system med tvangsarbejde. Men samtidig kom der veje, hospitaler og det første automatiske telefonsystem i Latinamerika. Det var ikke nok.

Det tog amerikanerne 18 år at 
indse, at de var på vej ud i intet. Firs år efter gentog USA eksperimentet med en invasion, der fjernede endnu en militærmand fra magten, og Aristide blev genindsat. Men USA opgav igen, slået af korruption, den altid nærværende vold og den ofte bizarre, altid egoistiske manipulering af den politiske klasse.

Det efterlod sig også en dårlig smag - afsløringen at antidemokratiske slyngler i de tidlige 1990'ere var på CIA’s lønningsliste i modstrid med Det Hvide Hus' politik.

Man kan undre sig over, om de aktuelle bestræbelser fra USA og FN vil gøre mere end at genetablere status quo fra før jordskælvet.
Det tvivler jeg meget på. Haiti farligt i går og farligt i dag - vil takket være Graham Greene altid fastholde verdens opmærksomhed.

Men om det nogensinde vil komme ud af armoden og den sadistiske vold, er umuligt at forudse. For efter to hundrede år synes mørke at have vundet over lys.

\section{Jonathan Power er kolumnist for om-} kring 50 aviser, herunder International Herald Tribune.

(Oversat fra engelsk af Vibeke Sperling) 